\title{
TORTIOUS LIABILITY RESPECTING NATURAL GAS PLANTS
}

\section{LIABILITY FOR FAILURE OF PLANT TO OPERATE AS DESIGNED*}

The purpose of this portion of the paper is to consider the legal principles which will apply to the following problem:

Oil operators A, B, F \& G are the sole working interest owners of an oil reservoir from which they are producing oil, together with a substantial amount of casinghead gas. A, B, F \& $G$ hire expert D to design a plant for the purpose of processing the casinghead gas. Also, A, B, F \& G hire expert contractor $C$ to construct the processing plant designed by $D$. $D$ and $C$ are experts with long experience in this field. After completion of construction of the processing plant it is found that the plant will not operate in accordance with $A, B, F$ \& G's specifications. The contracts entered into by $A, B, F \& G$ with $D$ and with $C$ are silent in respect of responsibility for design. Who is liable for the cost and expense of rectifying the plant so as to make it capable of meeting $A, B, F$ \& G's original specifications?

\section{Preliminary Observations}

In actual practice it is usual for the firm that designs a gas processing plant to carry out the actual construction of the plant under a single contract covering both design and construction and containing express provisions to the effect that the finished plant will operate so as to meet the strict warranties and performance guarantees set forth in the agreement. It is not meant to suggest that this practice is invariable. Many instances occur where a project is designed by one party and built by another.

For the purpose of dealing with the case before us, it will be assumed that contractor $\mathbf{C}$ in fact built the processing plant using proper materials and workmanship in strict accordance with the design produced by $D$ so that there will be no suggestion that the plant will not operate in accordance with A, B, F \& G's specifications because C failed to follow D's design. Similarly, it may be necessary to make other assumptions, e.g. that the gas analysis shown in A, B, F \& G's specifications does not vary from the analysis shown when the finished plant is in operation.

\section{No Liability on Part of $C$}

In the circumstances of this particular case it seems clear that $\mathrm{C}$ cannot be held liable for the cost of rectifying the plant to render it capable of meeting A, B, F \& G's original specifications. C merely contracted to construct the plant in accordance with D's design. There is no room for implication of other terms as $\mathbf{C}$ fully performed such contract using proper materials and workmanship. ${ }^{1}$ Moreover, it is not possible to disregard the contract and allege a wider liability in tort where the defendant has protection under a contract. ${ }^{2}$ Accordingly, $\mathrm{C}$ is not responsible if the result turns out to be unsatisfactory. To hold $\mathrm{C}$ liable, it would

- G. W. Brown, Canadian Fina Oll Limited, Calgary, Alberta.

1 See Hudson's Building Contracts 149 (8th ed. 1959) where it is stated "Normally an employer desirous of carrying out a major work engages an architect or engineer to design the work and relies on his skill and not on that of the contractor, and in that case there is no implication that the work as designed will answer its purpose. . . If plans and a specification are supplied to the bullder to work to, he will not normally plans and a specifre than carry out the work according to the plans and speciflcations in a workmanlike manner. though he may well be fully aware of the purpose for which the work is required."

2 Hall v. Brooklands Auto Racing Club, [1933] 1 K.B. 205, 213. 
have to be shown that the work was done badly or not in accordance with D's design.

\section{Liability, If Any, on Part of D}

Having absolved contractor $\mathbf{C}$ of responsibility in the matter, what is the basis for liability, if any, on the part of $\mathrm{D}$ who undertook to design a plant capable of meeting A, B, F \& G's specifications?

Admittedly, the contract with $D$ contains no express term with respect to responsibility for design. The first question to decide is whether such a provision could be implied on the basis that it clearly must have been in the contemplation of the parties. The law in this regard is admirably stated in Halsbury ${ }^{3}$ as follows:

A stipulation not actually expressed in a written contract can only be implied in cases where the court is satisfied that both parties intended that the stipulation should be part of the contract, and the more so if the contract is (as is usual in the case of building and engineering contracts) drawn in a technical manner and with an obvious attention to details. In any case no stipulation can be implied which is at variance with the express terms of the contract. The court will not readily permit onerous covenants to be implied.

But, on the other hand, stipulations which clearly must have been in the contemplation of the parties, or which necessarily arise out of the contractual relation between the parties, will be implied, for example, stipulations on the part of the employer to allow the builder to do the work, to give possession of the site, and to supply plans, and on the part of the builder to proceed diligently and to execute the work in a workmanlike manner. But there is no implied obligation upon the employer to indemnify the contractor against loss caused by the wrongful interference of a third party with the means of access to the site. The existence of custom which would annex incidents to a contract may be proved by parol evidence if the custom is reasonable, but not so far as to contradict the contract. The reasonableness of the custom is a question for the court, but evidence may be adduced to show that it is not a reasonable one.

What is sought to be implied here is a warranty or performance guarantee, and a more onerous covenant could scarcely be imagined. D would undoubtedly testify that such a term was not in fact contemplated by him and that if the contract contained such a term he would have been obliged to add substantially to his fee. It is submitted that the cases in the footnotes to the above passages from Halsbury clearly indicate that A, B, F \& G will be faced with an impossible task if they wish to rely on an implied stipulation in the contract with $\mathrm{D}$ as the basis for holding him liable for the cost of rectifying the plant to render it capable of meeting their specifications. Likewise, it would be impossible to make out the existence of a custom in this respect, having regard to the fact we are dealing with a highly technical and detailed engineering contract, and that contracts of this kind are made very infrequently. How much simpler it would have been if the matter had been covered by express provision in the contract!

It therefore becomes necessary to determine whether $A, B, F \& G$ can succeed if they frame their action against $D$ on the basis of negligence. It should be borne in mind that the case is not one of a general duty in tort to exercise a proper degree of care where failure to do so is likely to cause physical injury to persons or property, but is one which comes under the heading of duty to exercise special skill. In order better to understand the distinction, the following quotation is taken from a foreword by Lord Justice Denning to the work entitled Professional Negligence: ${ }^{*}$

3 Halsbury's Laws 434 (3d ed. Simonds 1955).

IJ. P. Eddy, Professional Negligence. 
We are so used to actions for negligence in collision cases and factory cases that we are apt to think the same principles apply to actions for negligence against professional men. This is a great mistake. One great difference is that an action against a solicitor, architect or accountant rests in contract and not in tort; and it avails only the party to the contract and no one else. Another difference is in the standard of care which is exacted. The courts have no hesitation in holding that mistakes made by car drivers or employers are visited by damages; but they make allowances for the mistakes of professional men. They realize that a finding of negligence against a professional is a serious matter for him. It is not so much the money, because he is often insured against it. It is the injury to his reputation which a finding of negligence involves.

Numerous other writers have dealt with the duty to exercise special skill. The principle is firmly established in our law that whenever the performance of an act depends on professional knowledge and skill, the actor is required to possess such knowledge and exercise such skill. The principle applies to most activities, although it is medical men, dentists, lawyers and accountants, who, in the exercise of their profession, have been involved in the majority of the reported cases. The standard of care which the law requires is that of the hypothetical reasonable man. This has been set out in numerous cases in slightly different ways, but one or two extracts from leading cases should be sufficient for our purposes. In Lamphier v. Phipos, ${ }^{3}$ which dealt with negligent treatment of a broken arm, Tindall, C. J., said:

Every person who enters into a learned profession undertakes to bring to the exercise of it a reasonable degree of care and skill. He does not undertake, if he is an attorney, that at all events you shall gain your cause, nor does a surgeon undertake that he will perform a cure; nor does he undertake to use the highest possible degree of skill. There may be persons who have higher education and greater advantages than he has, but he undertakes to bring a fair, reasonable, and competent degree of skill, and you will say whether in this case, the injury was occasioned by the want of such skill in the defendant.

In the case of Rex v. Bateman, ${ }^{6}$ a case arising from a criminal prosecution, Lord Chief Justice Hewart said:

If a person holds himself out as possessing special skill and knowledge and he is consulted, as possessing such skill and knowledge, by or on behalf of a patient, he owes a duty to the patient to use due caution in indertaking the treatment. If he accepts the responsibility and undertakes the treatment and the patient submits to his direction and treatment, accordingly, he owes a duty to the patient to use diligence, care, knowledge, skill and caution in administering the treatment. .. . The law requires a fair and reasonable standard of care and competence.

The principles enunciated in the above cases have been adopted by our Canadian Courts. ${ }^{?}$

Turning again to our particular problem, it must be realized that it is a question of fact in every case whether the actor did or did not exercise the measure of care that a reasonable man would have exercised in the particular circumstances. In the facts as set out in our hypothetical problem there is nothing to indicate that $D$ did not in fact possess the reasonable degree of skill and ability required or that he failed to exercise such skill. All we know is that when the plant was built in accordance with D's design it would not operate in accordance with $A, B$, F \& G's specifications. As we have already seen, a practitioner is not a guarantor of good results and is free from liability if he acted in accordance with recognized practice, and there is no suggestion that $D$

5 [1838] 8 Car. \& P. 475, 479.

641 T.L.R. 557, 559.

7 Jewison v. Hassard (1916), 26 Man. R. 571; Huston v. Jost, [1943] O.W.N. 3, 4; Gent \& Gent v. Wilson, [1956] O.R. 257, 265. 
did not do so. The evidence falls far short of what is required in similar situations. Thus, in Hunter v. Hanley, ${ }^{8}$ Lord President Clyde said:

To establish liability by a doctor where deviation from normal practice is alleged, three facts require to be established. First of all it must be proved that there is a usual and normal practice. Secondly it must be proved that the defender has not adopted that practice, and thirdly (and this is of crucial importance) it must be established that the course the doctor adopted is one which no professional man of ordinary skill would have taken if he had been acting with ordinary care.

To meet the three tests as laid down by Lord President Clyde would require direct evidence of a cogent nature which we simply do not have in the facts of the present case. It therefore appears that $D$ must be held not liable on the grounds of negligence for the cost and expense of rectifying the plant so as to enable it to meet the specifications of $A, B, F \& G$.

It is perhaps desirable to add a brief word concerning the possible application of res ipsa loquitor to the facts of the present case. There is some doubt whether this rule could have any application at all in a case of this kind. In the case of Clark v. Wansborough, ${ }^{9}$ McTague, J. A., as trial judge, stated flatly:

The doctrine of res ipsa loquitor, no matter how ingeniously put, has no application in malpractice cases.

There are, it is true, other decisions which do not agree with the foregoing dictum. However, even if the doctrine does apply to cases of this kind it is submitted that it is of no assistance in the problem before us. This is not a case where a "tell-tale" sponge or a pair of forceps was left inside a person's abdomen during an operation. We merely have a plant designed by $\mathrm{D}$ which will not operate in accordance with specifications. It is not "a proper and natural inference immediately arising" 10 that $\mathrm{D}$ must have been negligent.

\section{Summary}

With respect to $C$, the expert contractor, who undertook to construct the processing plant designed by $D$, we have assumed that $C$ used proper materials and workmanship and constructed the plant strictly in accordance with D's design. In these circumstances, the authorities indicate $C$ cannot be held responsible.

As regards $D$, who undertook to design a plant in accordance with A, B, F \& G's specifications, there are two possible grounds for liability, notwithstanding the contract contains no express term with respect to responsibility for design.

The first of these grounds concerns whether a stipulation or covenant ought to be implied. Here the authorities show that onerous covenants will not be implied, although a court will imply relatively innocuous and self-evident matters which "clearly must have been in the contemplation of the parties". It is submitted that a claim on this basis most likely would be unsuccessful.

The second possible basis of liability on the part of $D$ is negligence. As an expert, the law requires him to possess the necessary professional knowledge and skill and to exercise such skill. In the facts as set out in this problem there is no suggestion that $D$ lacked the necessary profes-

8 (1955), S.L.T. 213, 217.

o [1940] O.W.N. 67, 72.

1028 Halsbury's Laws 77 (3d ed. Simonds 1955). 
sional knowledge or failed to exercise the proper degree of skill. Additionally, a practitioner is not a guarantor of good results in all cases and the doctrine of res ipsa loquitor is of no application or assistance in attempting to establish that $\mathrm{D}$ must have been negligent. It therefore appears that the second possible basis of liability on the part of $D$ fails.

In conclusion, it seems clear that $A, B, F \& G$ have no recourse under the circumstances against either $C$ or $D$. As mentioned earlier, it is usual in contracts for design and construction of gas plants to include express provisions requiring that the finished plant will operate to meet strict warranties and performance guarantees as set out in the contract. If plant owners fail to protect themselves in this manner they will probably find that the courts are extremely reluctant to assist them by implying additional contract terms or by holding others negligent.

\section{LIABILITY FOR LOSSES DURING PLANT RECTIFICATION*}

\section{Introduction}

The facts of this problem are as follows:

Oil wells owned and operated by $A$ and $B$ are shut-in for six months because of failure of a casinghead gas processing plant owing to negligent design or construction by experts $\mathrm{D}$ and $\mathrm{C}$ respectively. As a result, $A$ and $B$ lose their leases and suffer loss of consortium with their wives. Are $D$ and $C$ responsible for the losses suffered by $A$ and $B$ ?

In examining the effect of the negligence of $D$ or $C$, one is inevitably led to the consideration of those vagaries of common law tort liability known as "foreseeability" and "remoteness".

Although there is a wealth of reported cases in this area of tort law it will only be necessary to consider the 1961 leading case of Overseas Tank Ship (U.K.) Ltd. and Morts Dock \& Engineering Co. Ltd., known as The Wagon Mound ${ }^{11}$ and the subsequent Canadian cases of Oke (Oke Estate) v. Government of Manitoba and Weide Transport Ltd. and Carra ${ }^{12}$ and Lauritzen v. Barstead and Wawanesa Mutual Insurance Company, ${ }^{13}$ which were decided by the Court of Appeal of Manitoba and by Kirby, J. of the Supreme Court of Alberta in 1963 and 1965, respectively.

In essence these cases held that "the essential factor in determining liability for the consequences of a tortious act of negligence is whether the damage is of such a kind as the reasonable man should have foreseen". Applying this test, it is submitted that D or C would not be held liable for the loss or damage suffered by $A$ and $B$.

\section{Historical Development of Negligence}

Before dealing with specific cases on the subject, it might be worthwhile to put the problem in proper perspective by briefly reviewing the historical development of negligence as an independent basis of tort liability up until the advent of Polemis v. Furness, Withy \& Co., known as The Polemis Case, ${ }^{14}$ which was the leading case in this field for some forty years from 1929 until The Wagon Mound Case.

- W. M. Winterton, British American Oil Company Limited, Calgary, Alberta.

11 [1961] A.C. 388.

12 (1963), 43 W.W.R. 203.

13 (1965), 53 W.W.R. 207.

14 [1921] 3 K.B. 560. 
John G. Fleming, in his article entitled Passing of Polemis, ${ }^{15}$ tells us that soon after negligence emerged in the early 19th century as an independent basis of tort liability from misty, and still rather obscure, beginnings, the Great Debate was joined over the extent of responsibility for the consequences of all negligent conduct.

As early as 1850 , Pollock, C.B., in Greenland v. Chaplin ${ }^{16}$ affirmed that "liability should not reach beyond consequences which the defendant could reasonably have anticipated as likely to occur". From the viewpoint of history, it is hardly surprising that this limiting formula would gain ascendency for some time to come over competing theories whose acceptance would have involved a more far-reaching measure of liability. Its practical effect was to allay the genuine fear of imposing too heavy a burden on society or opening the floodgates of litigation. On many occasions during the next half century it served to shield defendants by warding off the impact of liability in situations where injury became a consequence which in the ordinary course of things would not flow from the negligence.

Since the patern of legal development was not then, or ever has been, uniform, it was natural that resistance to foreseeability as the criterion for defining the extent of liability for negligence developed. This was first evidenced when the interest of plaintiffs gained support in Smith v. London and South Western Railway, ${ }^{17}$ when three members of the Court, in obiter dicta, declared themselves in favour of the view that, once negligence has been established against a defendant, liability is attached for all its consequences, regardless of whether they were foreseeable or not. So far-reaching a proposition had to be harnessed in some manner, since it clearly would have been unthinkable to accept "liability for all of the consequences" in its quite literal sense. Therefore some stabilizing device became apparent. This was eventually found in the much abused formula of "directness", the chief blame for which may fairly be laid at Lord Sumner's door. In 1920, in Weld-Blundell v. Stephens ${ }^{18}$ he lent his prestige to this development by stating "the presence or absence of reasonable anticipation of damage determines the legal quality of the act as negligent or innocent. If it be thus determined to be negligent, then the question whether particular damages are recoverable depends only on the answer to the question whether they are direct consequences of the act".

As was almost inevitable, the rule of liability for all direct consequences was ready to be exploited for an end diametrically opposed to that which it was originally designed to promote. Henceforth, but with few exceptions, it was to give succour to plaintiffs, not defendants. Fashioned with the intent of restricting liability to an even narrower radius than the foresight test, it became the open door for allowing it to escape beyond.

Within little more than a year, Lord Sumner's formula was in fact applied in The Polemis Case in a manner which seemed to many contemporary observers to have committed English law to a startling change of direction. However, several antedotes were soon at work to counteract this change. In the first place, the foreseeability criteria was im-

1539 Can. Bar Rev. 489.

16 [1850] 5 Ex. D. 244.

17 [1870] L.R. 6 C.P. 14.

18 [1920] A.C. 956. 
perceptibly restored to its role of defining the extent of liability for "indirect" consequences. The postulate of "no liability for other than direct consequences, however foreseeable" was replaced by "liability (at least) for all foreseeable consequences, whether direct or indirect". Aided by the indeterminacy of the term "direct", there were few occasions when causal problems were not so classified as to fall for decision on the basis of the foresight test because they involved the subsequent intervention of new factors between the defendant's original negligence and the eventual harm.

\section{The Polemis Case}

In The Polemis Case a ship owned by the plaintiffs was destroyed by fire while being unloaded by workmen employed by the defendant charterers. Experienced arbitrators held that the fire was caused by a spark igniting benzene vapours which had leaked from cargo in the hold and that the spark was caused by workmen negligently knocking a plank into the hold.

The defence was that there was no negligence for which the defendants were responsible because letting a board fall into the hold of the ship could do no harm to the ship and therefore was not negligence towards the plaintiffs; and that the damage which resulted was too remote to be reasonably foreseeable as the consequence of the falling of the plank.

It was held by the Court of Appeal that, as the fall of the plank was due to the negligence of the defendants' servants, the defendants were liable for all the direct consequences of the negligent act, even though those consequences could not reasonably have been anticipated and therefore the defendants were liable for the loss of the ship by fire. It was also held that the question whether the damage could reasonably have been anticipated was relevant only to the question whether the act was or was not negligent.

The Polemis Case therefore became the authoritative decision with respect to remoteness of damages. The rule laid down by the Court was summarized by Rand, J. in Cook v. Lewis ${ }^{19}$ in these words: ${ }^{20}$

... if $A$ is guilty of a negligent act towards $B$, the total direct consequences of that act are chargeable against $A$ notwithstanding that they arise from reactions unforeseeable by the ordinary person acting reasonably; ... the presence of benzene was known, but that a spark could occur in the fall of a plank into the hold sufficient to set off an explosion, although a potentiality of the total circumstances, was outside the range of anticipation; a falling plank might do some damage to the ship, but would not ordinarily be associated in the impact on wood or iron with fire, and, a fortiori, with sparking explosive fumes.

There is a long line of decisions in which the direct-consequence rule has been followed. These decisions were exhaustively reviewed by Egbert, J. in Duce v. Rourke; Pearce v. Rourke. ${ }^{22}$ However, this rule was decisively rejected in the decision of the Privy Council in The Wagon Mound Case.

\section{The Wagon Mound Case}

The facts in The Wagon Mound Case were that in the course of refuelling the tanker, Wagon Mound, moored to the Caltex wharf at Sydney

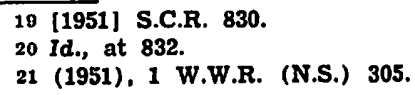


Harbour, Australia, a considerable quantity of furnace oil was carelessly allowed to overflow from one of its bunkers into the water where it spread and was carried by wind and tide to the plaintiff's wharf, some 600 feet away, where another vessel, the Corrimal, was undergoing extensive repairs. Although alerted, neither Caltex nor the charterers of the Wagon Mound made any attempt to disperse the oil, in the belief supported by expert testimony at the trial, that there was no recognizable fire hazard because of the high flash point of oil floating on water. The repair work aboard the Corrimal involved the use of electric and oxyacetylene welding equipment. Two days later, however, the oil, which had in the meantime remained in an unchanged condition around the plaintiff's wharf, suddenly burst into flames and severely damaged the wharf and the Corrimal. Subsequent scientific experiments supported the hypothesis, accepted as a fact by the trial judge, that the fire must have been set off by a "wick" when molten metal fell from a dock upon cotton waste floating beneath and ignited the surface oil.

In an action for damages the Privy Council proceeded on the view that the problem presented by The Wagon Mound Case was substantially the same as that litigated in The Polemis Case, but, in a bold judgment, Viscount Simonds reached the opposite conclusion from that of the Court of Appeal 40 years earlier by stating that The Polemis Case was not good law. In effect Viscount Simonds held that the essential factor in determining liability for the consequences of a tortious act of negligence is whether the damage is of such a kind as the reasonable man should have foreseen. Liability does not depend solely on the damage being the "direct" consequence of the precedent act; but if a man should not be held liable for damage unpredictable by a reasonable man because it was "direct" or "natural", equally he should not escape liability, however "indirect" the damage, if he foresaw or could have reasonably foreseen the intervening events which led to its occurrence. Foreseeability is thus the effective test-the "direct" consequences test leads to nowhere but the never-ending and insoluble problems of causation. There is not one criterion for determining culpability (or liability) and another for determining compensation; unforeseeability of damage is relevant to liability or compensation-there can be no liability until the damage has been done. It is not the act but the consequences on which tortious liability is founded. ${ }^{22}$

After reviewing several decisions departing from the rule in The Polemis Case, Viscount Simonds said: ${ }^{23}$

Enough has been said to show that the authority of Polemis has been severely shaken, though lip-service has from time to time been paid to it. In their Lordships' opinion, it should no longer be regarded as good law. It is not probable that many cases will for that reason have a different result, though it is hoped that the law will be thereby simplified, and that, in some cases at least, palpable injustice will be avoided. For it does not seem consonant with current ideas of justice or morality that, of an act of negligence, however slight or venial, which results in some trivial foreseeable damage the actor should be liable for all consequences however unforeseeable and however grave, so long as they can be said to be "direct". It is a principle of civil liability, subject only to qualifications which have no present relevance, that a man must be considered to be responsible for the probable consequences of his act. To demand more of him is too harsh a rule, to demand less is to ignore that civilized order requires the observance of a minimum standard of behaviour. This concept, applied to the

2:2 The implications of the Wagon Mound Case are explored in A. M. Honore, 39 Can. Bar. Rev. 267, and John G. Fleming, The Passing of Polemis, 39 Can. Bar Rev. 489.

2is Ante, n. 11, at 413. 
slowly developing law of negligence has led to a great variety of expressions which can, as it appears to their Lordships, be harmonized with little difficulty with the single exception of the so-called rule in Polemis. For, if it is asked why a man should be responsible for the natural or necessary or probable consequences of his act (or any other similar description of them) the answer is that it is not because they are natural or necessary or probable, but because, since they have the quality, it is judged by the standard of the reasonable man, that he ought to have foreseen them. Thus it is that, over and over again, it has happened that, in different judgments in the same case and sometimes in a single judgment, liability for consequence has been imposed on the ground that it was reasonably foreseeable, or alternatively on the ground that it was natural or necessary or probable. The two grounds have been treated as coterminous, and so they largely are. But, where they are not, the question arises to which the wrong answer was given in Polemis. For, if some limitation must be imposed upon the consequences for which the negligent actor is to be held responsible-and all are agreed that some limitation there must be-why should that test (reasonable foreseeability) be rejected which, since he is judged by what the reasonable man ought to foresee, corresponds with the common conscience of mankind, and a test (the "direct" consequence) be substituted which leads to nowhere but the never-ending and insoluble problems of causation.

\section{Viscount Simonds further on made these general observations: ${ }^{24}$}

Their Lordships conclude this part of the case with some general observations. They have been concerned primarily to displace the proposition that unforeseeability is irrelevant if damage is "direct". In doing so they have inevitably insisted that the essential factor in determining liability is whether the damage is of such a kind as the reasonable man should have foreseen. This accords with the general view thus stated by Lord Atkin in Donoghue v. Stevenson, ${ }^{25}$

'. . The liability for negligence, whether you style it such or treat it as in other systems as a species of 'culpa', is no doubt based upon a general public sentiment of moral wrongdoing for which the offender must pay.'

It is a departure from this sovereign principle if liability is made to depend solely on the damage being the "direct" or "natural" consequence of the precedent act. Who knows or can be assumed to know all the processes of nature? But if it would be wrong that a man should be held liable for damage unpredictable by a reasonable man because it was "direct" or "natural", equally it would be wrong that he should escape liability, however "indirect" the damage, if he foresaw or could reasonably foresee the intervening events which led to its being done. Thus foreseeability becomes the effective test. In reasserting this principle their Lordships conceive that they do not depart from, but follow and develop, the law of negligence as laid down by Alderson, B., in Blyth v. Birmington Waterworks Co.26 It is proper to add that their Lordships have not found it necessary to consider the so-called rule of "strict liability" exemplified in Rylands v. Fletcher ${ }^{2}$ and the cases that have followed or distinguished it. Nothing they have said is intended to reflect on that rule.

\section{Application of the Rule of Foreseeability}

The rule of foreseeability in The Wagon Mound Case has been applied by the Court of Appeal in Doughty v. Turner Mfg. Co. ${ }^{23}$ and in Canada by the Manitoba Court of Appeal in Oke (Oke Estate) v. Government of Manitoba and Weide Transport Ltd. and Carra ${ }^{20}$ and by Kirby, J. in Lauritzen v. Barstead and Wawanesa Mutual Insurance Company. ${ }^{30}$

In the Oke Case the defendant, without fault, knocked down a traffic sign situated on a gravel divider in the centre of a divided highway. He removed the loose debris but left a metal post protruding from the ground, being unable to remove it. He intended, but failed, to report this state of affairs. Thirty-six hours later, plaintiff was speared by the post and killed when pulling onto the gravel divider in order to pass a

\footnotetext{
24 Ante, n. 11, at 426.

$25[1932]$ A.C. 562,580 .

26 [1856] 11 Exch. 781, 784.

27 [1868] L.R. 3 H.I. 330 .

28 [1964] 1 Q.B. 518.

29 Ante, n. 12.

80 Ante, n. 13.
} 
vehicle ahead. The gravel divider was not intended for the use of traffic.

Miller, C. J. M., Schultz and Guy, J. J. A., concluded that the use of the gravel divider by the plaintiff was unusual and unexpected, and could not have reasonably been foreseen by the defendant, whereas Freedman, J. A. (Monnin, J. A. concurring) dissented on the grounds that to hold the defendant liable would not be to depart from the reasoning in The Wagon Mound Case. The accident in question was reasonably foreseeable by the defendant in that it was clearly a source of danger to any motorists who should enter on the gravel divider. The defendant himself entered thereon in knocking down the sign and the likelihood of another doing the same must have been in his mind to account for his clearing up the debris and forming the intention to report the occurrence.

In Lauritzen v. Barstead and Wawanesa Mutual Insurance Company, ${ }^{31}$ the plaintiff was driving the defendant's car along a remote country road in slippery conditions on a cold night; defendant, who was intoxicated and was in the passenger seat, ordered plaintiff to turn off the road at a certain point so that he could go to a small town to buy some beer. Plaintiff refused, whereupon defendant grabbed the steering wheel, causing the car to go off the road into a ditch, from which it could not be extricated. Later, the defendant drove the car across the open prairie to a river where it became stuck in a hole. By reason of exposure and by reason of attempts to go for help, plaintiff suffered severe frostbite necessitating amputation of parts of both feet.

In addition to claiming damages for the loss of parts of both of his feet, the plaintiff also claimed damages for loss of consortium suffered when his wife left him because she did not want to live with a crippled man.

In his decision Kirby, J. stated that "It does not seem to me that the decision in The Wagon Mound Case implies that recovery of damages should be conditional upon foreseeability both of the particular harm and the precise manner or sequence of events in which it occurred". He went on to hold that the defendant should have foreseen the dangerous consequences likely to flow from his negligent act in grabbing the steering wheel and that, applying the test laid down in The Wagon Mound Case, the plaintiff was entitled to be compensated for the damages he had suffered. His claim for loss of consortium suffered when his wife left him was held to be too remote.

\section{Conclusion}

In the light of the cases considered and by applying the now strongly accepted test of foreseeability, it is difficult to imagine that C or D (whether experts or not) could possibly have foreseen the consequences of their negligence which befell A and B. It is therefore concluded that "if the test of foreseeability was applied on an objective rather than on a subjective basis," a court would probably hold that both the loss of the leases and the loss of consortium experienced by A and B would be too remote to entitle them to recover compensation from $\mathrm{D}$ or $\mathrm{C}$. 


\section{LIABILITY FOR DELIVERING $\mathrm{H}_{2} \mathrm{~S}$ GAS WHICH DAMAGES PLANT*}

\section{Introduction}

The stated problem is that A, B, F \& G each transports his casinghead gas into a processing plant through a separate line. A batch of gas loaded with $\mathrm{H}_{2} \mathrm{~S}$ was negligently allowed to enter the plant and the $\mathrm{H}_{2} \mathrm{~S}$ has impaired the plant operations. It was established that the sour batch of gas came from the wells of $\mathrm{F}$ or $\mathrm{G}$, but it is impossible to establish which one.

Some scepticism must be expressed, in passing, concerning these facts. It is difficult to credit an inability to lay responsibility at the proper doorstep when the casinghead gas comes to the plant through separate lines. The Operator of the plant, if acting in a reasonable and prudent manner, would have better control over incoming substances. It might be presumed that if the Operator of the plant has not provided an adequate check of incoming substances he may then have to suffer the consequences which, in this case, must be that the Operator cannot recover from either $\mathbf{F}$ or $\mathbf{G}$.

In any event, accepting the facts as given, the question is: from whom can the plant owner recover the costs and expenses incurred by it in repairing the plant?

The answer is given in the judgment of Mr. Justice Cartwright in Cook v. Lewis:

The general rule is, I think, stated correctly in Starkie on Evidence, 4th ed. p. 860, quoted with approval by Patterson, J. A. in Moxley v. Can. Atlantic $R y$. (1887) 14 O.A.R. 309 at p. 315: "Thus in practice, when it is certain that one of two individuals committed the offence charged, but it is uncertain whether the one or the other was the guilty agent, neither of them can be convicted."

This rule, I think, is also applicable to civil actions so that if at the ond of the case $A$ has proved that he was negligently injured by either $B$ or $C$ but is unable to establish which of the two caused the injury, his action must fail against both unless there are special circumstances which render the rule inapplicable. ${ }^{32}$

\section{Cook v. Lewis Examined and Criticized}

However, in Cook v. Lewis the Supreme Court of Canada did not follow this principle of law. In fact, the Court took a contrary position which would give the plant operator in the case under discussion a right of recovery. For the reasons set out in this paper, it is our respectful opinion that the decision in Cook v. Lewis is wrong, and that the plant operator is barred from recovering his damages because of his inability to attribute responsibility to the rightful cause.

In Cook v. Lewis, a party consisting of A, B and C was grouse shooting in the vicinity of Quinsam Lake on Vancouver Island. $X, Y$ and $Z$ made up another party which was similarly engaged. As $A, B$ and $C$ in line approached a clump of trees, $\mathrm{Z}$, who saw them and anticipated danger to $\mathrm{X}$, who was in that particular clump, called out a warning. This warning was misunderstood by $A$, who thought that $Z$ was referring to B's dog, and B said that he did not hear it at all. Just then a covey of grouse flew up and both A and B fired. There was a scream from the thicket and $X$ appeared. He had been shot in the face and eventually lost the sight of an eye. Both $A$ and $B$, of course, denied

- J. M. Killey, Shell Canada Limited, Calgary, Alberta, and G. F. Hulme, TransCanada Pipe Lines Ltd., Calgary, Alberta.

32 Cook v. Lewis, [1951] S.C.R. 830, 840; [1952| I D.L.R. 1, 15. 
shooting $X$. It is sufficient to assume that it was impossible to decide who fired the shot, even on the balance of probabilities, since this was the approach of the Supreme Court.

These facts were without precedent in Canada or in England. ${ }^{33}$

An analysis of the case illustrates that the Court was obviously sympathetic to the plaintiff and was determined to give him redress. It is respectfully submitted that in doing so the Court was led into a marked departure from a well established principle with which the decision in Cook v. Lewis cannot be reconciled. It is further respectfully submitted that if Cook v. Lewis illustrates any principle it is that difficult cases make bad law.

The essence of the approach of Rand, J. is as follows:

What, then, the culpable actor has done by his initial negligent act is, first, to have set in motion a dangerous force which embraces the injured person within the scope of its probable mischief; and next, in conjunction with circumstances which he must be held to contemplate, to have made more difficult if not impossible the means of proving the possible damaging results of his own act or the similar results of the act of another. He has violated not only the victim's substantive right to security, but he has also culpably impaired the latter's remedial right of establishing liability. By confusing his act and environmental conditions, he has, in effect, destroyed the victim's power of proof.

The legal consequences of that is, I should say, that the onus is then shifted to the wrongdoer to exculpate himself; it becomes in fact a question of proof between him and the other and innocent member of the alternatives, the burden of which he must bear. The onus attaches to culpability, and if both acts bear that taint, the onus or prima facie transmission of responsibility attaches to both, and the question of the sole responsibility of one is a matter between them. ${ }^{34}$

Rand, J. shifts the burden of proof to the defence-but this is not a case where res ipsa loquitur applies. ${ }^{35} \mathrm{He}$ is eager to protect the victim's remedial right of establishing liability-but no such right is known. He burdens the defendants with the responsibility of disproving the plaintiff's claim and adds a pious hope, of no probative value, that no liability will attach to an innocent act of shooting. He does not consider that, although innocent, a defendant may be unable to discharge the onus thus cast on him. In his concern for the plaintiff, he quite ignores the rights of the innocent one of the defendants.

It was Cartwright, J., (speaking for Estey and Fauteux, J. J.), who set forth the general rule first quoted. He went on to specify that no "special circumstances" exist in Cook v. Lewis" and then said:-

The judgment in Summers v. Tice, (5 A.L.R. (2d) 91), reads in part as follows (p. 96): "When we consider the relative position of the parties and the results that would flow if plaintiff was required to pin the injury on one of the defendants only, a requirement that the burden of proof on that subject be shifted to defendants becomes manifest. They are both wrongdoers-both negligent toward plaintiff. They brought about a situation where the negligence of one of them injured the plaintiff, hence, it should rest with them each to absolve himself if he can. The injured party has been placed by defendants in the unfair position of pointing to which defendant caused the harm. If one can escape the other may also and plaintiff is remediless. Ordinarily defendants are in a far better position to offer evidence to determine which one caused the injury. This reasoning has recently found favour in this Court."

I do not think it necessary to decide whether all that was said in Summers $v$. Tice should be accepted as stating the law of British Columbia, but I am of opinion, for the reasons given in that case, that if under the circumstances of the case at bar the jury, having decided that the plaintiff was shot by either Cook or Akenhead, found themselves unable to decide which of the two shot

33 Id., at 834.

if Id., at 832 and 833

35 See Wright, Res Ipsa Loquitur, (1955) Special Lectures of the Law Soclety of Upper Canada, at 103 .

3i: Ante, n. 32. 
him because in their opinion both shot negligently in his direction, both defendants should have been found liable. ${ }^{3 i}$

Our comments on the judgment of Rand, J. are applicable here. As well, Cartwright, J. appears to have contradicted himself when he said:

The American case of Summers v. Tice, (5 A.L.R. (2d) 91), relied upon by the respondents is, I think, properly distinguished in the reasons for judgment of Sidney Smith, J. A. The decisive finding of fact in that case was that both of the defendants had shot in the direction of the plaintiff when they knew his location. There is no such finding in the case at bar. ${ }^{38}$

Cook v. Lewis was warmly welcomed by Dr. Glanville L. Williams a

Dr. Williams saw Cook v. Lewis as establishing the principle that where two defendants have committed acts of negligence in circumstances that deprive the plaintiff of the ability to prove who caused his damage, the burden is cast on each defendant to exculpate himself, failing discharge of this burden, both are liable.

His only complaint, indeed, is that the Supreme Court of Canada did not go far enough. He says:

The recognition of this principle is an important contribution, both to the law of tort and to the law of evidence. It makes a big exception to the rule, recognized by the judges, that where a plaintiff cannot establish which of two defendants did the damage he must generally fail. It seems that this rule now operates only where one defendant (but it cannot be said which) was wholly free from blame. One may, indeed, question whether the rule is a good one even when limited in this way. To deny a remedy means that justice is certainly not done; to give a remedy would mean a fifty percent possibility that justice is done. ${ }^{40}$

It is respectfully suggested that Dr. Williams is not on sound ground. The facts of the case do not support his assumption that both defendants in Cook v. Lewis were blameworthy. Dr. Williams is guilty with Rand, $\mathrm{J}$. in his disregard for the rights of the defendant. His suggestion that to give the plaintiff a remedy would mean a fifty percent possibility that justice is done ignores the fact that this remedy is an injustice to one of the defendants mitigated only by the fact that that defendant is liable for only one-half of the quantum. It is our opinion that this is no mitigation at all.

... it is submitted that to hold all the defendants liable because the actual wrongdoer is unknown would be little short of monstrous. It involves saying that an entirely innocent defendant can be made liable in damages because, through the existence of circumstances over which he has no control, except perhaps intermittently, he is at the scene of the commission of a tort by some person or persons unknown. It involves saying that because the defendant cannot prove his innocence, his guilt is to be assumed, and that is clearly wrong."1

\section{Conclusion}

Having disagreed with Dr. Williams, what is the right answer? We must, with respect, agree that:-

... the conclusion must be that unless all the defendants are joint, or several concurrent, tortfeasors the plaintiff must fail if from a number of defendants he cannot put his finger on the tortfeasor even though it is proved that the tortfeasor must be one of them. It is thought that this conclusion is not only the inevitable conclusion in law but also the conclusion which is required by good sense.42

In our view the gas plant problem falls in this category. On the facts given, therefore, our opinion is that the plant operator is left without a remedy.

3 inte, n. 32, at 842 and 15 .

38 Ante, 32 , at 840 and 16.

30 In a comment, 31 Can. Bar Rev. 315.

40 Id., at 317 .

4 Id., at 317.

12 Id., at 344. 


\section{LIABILITY FOR AIR POLLUTION BY NATURAL GAS PROCESSING AND SULPHUR RECOVERY PLANTS*}

\section{Problems and Effects of Air Pollution}

The increasing number of natural gas processing and sulphur recovery plants in the Province of Alberta has created concern about the risk of injury to life and property caused by disposal of odorous, noxious and toxic waste gases from such plants and the risk of tort liability of plant operators, plant owners and other persons who supply natural gas to such plants for processing. Usually, there is little or no risk in the disposal of waste gases in processing sweet natural gas, but the risk is greatly increased in the disposal of waste gases in processing sour natural gas which contains deleterious substances harmful to persons and property. These deleterious substances are sulphur dioxide and mercaptans with lesser amounts of hydrogen sulphide and other substances. Of special concern in processing sour natural gas is the problem of how to dispose of hydrogen sulphide and eliminate its release into the atmosphere along with other foul smelling waste gases such as mercaptans. Within practical limits all of these waste gases are incinerated and converted to sulphur dioxide before they are emitted into the atmosphere. This procedure, while effective in reducing complaints of odours, creates a problem in the disposal of sulphur dioxide. In most cases this problem is eliminated by the construction of waste gas disposal stacks of adequate heights to allow sufficient dispersion of sulphur dioxide into the atmosphere so that sulphur dioxide at ground level is consistently below the odour and injury concentration levels. However, unpredictable wind and atmospheric conditions occasionally may interfere with proper dispersion of the waste gases and result in injury to life and property.

Some of the reported effects of certain concentrations of hydrogen sulphide, sulphur dioxide and mercaptans in the atmosphere are as follows: ${ }^{43}$

Effects

Noticeable odour@

Irritating to cyes, nose and throat @.....

Accepted concentration for industrial working conditions

Inhibits human sense of smell @ ..........

Hazardous to life

Produces instant death

Threshold for damage to vegetation ......

Tarnishes paint and silverware

Accelerates rusting of iron and steel ....

Concentrations at Ground Level in Parts per Million by Volume

Hydrogen Sulphide Sulphur Dioxide

$0.1 \quad 3.0$

$\begin{array}{ll}20-90 & 10.0\end{array}$

20

100

300-1000*

$1 \%(10,000)$

20-40

0.1 $\mathbf{5 . 0}$

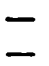

-

$0.3^{* *}$

$-$

varies with

humidity but

$\mathrm{SO}_{2}$ worse than

- At 300 p.p.m., the exposure may be over a matter of hours while at 1,000 p.p.m. there is almost instantaneous unconsciousness.

**The effect of sulphur dioxide varies with the type of vegetation, the time of exposure and the concentration during the exposure. For sensitive plants, 0.3 p.p.m. for 8 hours is the threshold condition and 1.0 p.p.m. for 1 hour and 1.5 p.p.m. for 3 minutes are similar.

- John F. Curran, Pan American Petroleum Corporation, Calgary, Alberta.

43 In modified form from an unpublished paper entitled General Aspects of Air Pollution in Alberta by S. L. Dobko. P. Ens., Head. Air \& Water Pollution Control Section, Department of Public Health. Government of the Province of Alberta. 
Mercaptans are produced in sweetening propane, butane and condensates. They have a very strong and offensive odour which may be detected in concentrations in the air of about one one-thousandth's of one part per million parts of air. This is about one one-thousandth of the detectible level of hydrogen sulphide. Mercaptans will tarnish silver in concentrations of 0.1 parts per million.

This paper considers whether a plant operator, plant owners and other persons who supply natural gas to plants for processing may be held liable in tort for injury to life and property caused by deleterious substances in waste gases which are emitted into the atmosphere from the plants. ${ }^{44}$

\section{Statutory Control of Air Pollution}

Air pollution in the Province of Alberta is controlled by the Provincial Department of Public Health under authority of The Public Health Act. ${ }^{45}$ Section $7(1)(u)$ of The Public Health Act gives the Provincial Board of Health authority to make regulations for the prevention, mitigation and supression of disease and in particular for the prevention of the pollution of the atmosphere and the regulation of plants discharging waste matter into the atmosphere. Section $7(1)$ (u1) gives the Provincial Board of Health authority to regulate and prohibit construction of any plant where it is likely to create a problem of pollution. There is no doubt that this legislation is extremely broad and conceivably gives the Provincial Board of Health unlimited powers in respect of the construction and operation of natural gas processing and sulphur recovery plants. Pursuant to these sections, regulations for the control of air pollution came into force on September 15, 1961. ${ }^{46}$

Section 2 of the Provincial Board of Health's regulations sets forth the requirement that plans and specifications for plants must be submitted to the Provincial Board of Health for approval. Section 7 declares that plants in existence or under construction prior to September 15,1961 are exempt from the regulations for a period of five years or for such shorter period as the Provincial Board of Health deems to be in the public interest.

The standards for air pollution control are set forth in Sections $\mathbf{5}$ and 6 of the regulations. With respect to "odorous materials" the standard is non-interference with use and enjoyment of property and the health or safety of the public, and with respect to "toxic or noxious materials", it is the Provincial Board of Health's " 'calculated' maximum ground level concentration of the material which will occur".47

The legislation in the Province of Alberta which relates generally to natural gas processing is The Oil and Gas Conservation Act. ${ }^{48}$ The relevant provisions of this statute are as follows:

38. No scheme for...

(b) the processing ... or disposal of gas ...

shall be proceeded with unless the Board, by order, has approved the scheme upon such terms and conditions as the Board may prescribe.40

44 It should be noted that in the usual case the working interest owners of the reservoir delivering natural gas to the plant are also the owners of the plant, each owning a share of the plant equal to the percentage of plant capacity necessary for processing their gas, and the plant operator is usually the plant owner who owns the largest share of the plant.

45 R.S.A. 1955, c. 255.

46 (1961) Alberta Regulations 530- "Regulations for the control of air pollution".

47 From p. 2 of paper 65-48, presented to the Air Pollution Control Association Conference in Toronto, Ontario, entitled "Air Pollution in Alberta-Description of the Control Program and Analysis of Data Obtained". March, 1965.

48 S.A. 1957, c. 63.

10 S.A. 1957 , c. 63, s. 38 , as amended by S.A. 1960 , c. 74, s. 7 (a). 
38a. The performance of . . any scheme approved under Section 38 shall not be prevented or restrained by an injunction, judgment or order of any court.so

A plant operator cannot undertake or proceed with construction of a plant until it has obtained from the Provincial Board of Health approval in writing of the plans and specifications of the proposed plant. Likewise, no scheme for the processing or disposal of gas is to be proceeded with unless the Oil and Gas Conservation Board by order has approved the scheme. In practice, the Division of Sanitary Engineering of the Department of Public Health reviews the plans and specifications of the proposed plant and when it is satisfied that the plans and specifications are sufficient to reduce the possibility of air pollution, it recommends to the Provincial Board of Health that approval be given to the plant operator. The approval takes the form of a letter from the Provincial Board of Health addressed to the plant operator and is made subject to cancellation or amendment if the actual operations of the plant are not in accordance with the proposed operations. The Oil and Gas Conservation Board as a matter of practice will not approve a gas processing or sulphur recovery scheme unless and until the Provincial Board of Health has given its approval.

A plant operator is prohibited by the Provincial Board of Health's regulations from releasing or permitting escape of odorous gases into the atmosphere at such a rate as to interfere with use and enjoyment of property or to endanger the health or safety of the public, ${ }^{31}$ and it may only release toxic or noxious gases into the atmosphere after written approval has been obtained from the Provincial Board of Health and then only in such amounts and under such controls and safeguards as may be specified by the Provincial Board of Health.s2 It should be observed that no approval is required to emit odorous materials into the atmosphere whereas approval is required to emit toxic or noxious gases. However, in either case, the Provincial Board of Health's regulations clearly manifest concern that no emission of waste gases shall be allowed which may interfere with the use and enjoyment of property or endanger the health or safety of the public.

\section{Statutory Authority to Commit a Nuisance}

It is important that a plant operator obtain written approval of the plant plans and specifications from the Provincial Board of Health before emitting any odorous, toxic or noxious gases into the atmosphere. ${ }^{58}$ With respect to the question of tortious liability, a possible result of obtaining such approval is suggested by Clerk \& Lindsell on Torts: ${ }^{54}$

Where a statute has authorized the doing of a particular act, or the user of land in a particular way, which act or user will inevitably involve a nuisance, all remedy whether by indictment or by action for damages resulting therefrom is taken away, providing every reasonable precaution consistent with the exercise of the statutory powers has been taken to prevent the nuisance occurring. The burden of proving that a nuisance is inevitable lies on the person having a statutory authority. It is discharged by showing that all reasonable care and skill, according to the state of scientific knowledge of the time, has been taken.

This statement sets forth succinctly an argument that a defendant might rely on in the event it is charged with responsibility for operating a

so S.A. 1960 , c. 74, s. 8.

o1 Ante, n. 46, 8. 14-5-1.

32 Ante, n. 46, s. 14-6-1.

63 Ante, n. 46, B. 14-2-4.

s1 12 th ed., 8. 1279 , at 680 . 
plant in a manner which interferes with use and enjoyment of property or causes personal injury or property damage. This statutory immunity is founded on the presumption that reasonable precaution consistent with exercise of the authority and scientific knowledge has been taken to prevent the nuisance and that the nuisance is inevitable. Whether it can be said that present scientific knowledge is inadequate to completely control emissions of waste-gases from natural gas processing plants is doubtful and of greater doubt is whether nuisance created by waste gases is the inevitable consequence of operating these plants. However, the possibility of this defence should not be overlooked or ignored by any of the parties involved in litigation.

The defence of statutory authority is available to the defendant only if its authority is imperative and not merely permissive. If the authority is in substance permissive the defendant must operate the plant so as not to cause loss or damage to occupants of neighbouring lands, but if it is in substance imperative the defendant is empowered, short of negligence, to inflict any amount of injury without incurring responsibility. In the leading case of Canadian Pacific Railway Company v. Parke Lord Watson of the Privy Council stated that:

Their Lordships think that the judges of the Supreme Court were right in considering the crucial question in this case to be whether the Columbian legislation which they had to construe was ... imperative, or merely permissive. ${ }^{36}$

Whenever, according to the sound construction of a statute, the Legislature has authorized a proprietor to make a particular use of his land, and the authority given is, in the strict sense of law, permissive merely, and not imperative, the Legislature must be held to have intended that the use sanctioned is not to be in prejudice of the common law right of others. ${ }^{5 i}$

$\therefore$ it is encumbent upon them (the respondents) to shew that the Legislature deliberately intended to take away the rights of individuals to protect their property against invasion. 58

The Parke case gives no guidance as to when a statute is imperative or is merely permissive. However, in Maunsell v. Lethbridge Northern Irrigation District, ${ }^{50} \mathrm{Mr}$. Justice Stuart of the Appellate Division of the Supreme Court of Alberta discussed this aspect of the Parke case and stated: ${ }^{80}$

I confess that I have had some difficulty in arriving at a clear understanding of the principle of the distinction drawn by Lord Watson in C.P.R. v. Parke between "permissive" and "imperative" authority. It is, of course, fairly clear as to what was meant by the merely permissive authority declared in that case to have been given by statute. ... But just exactly what was meant by an "imperative" authority does not appear to be so plain. . . I I gather that what Lord Watson there said amounts to this that when once the Company has exercized its authority, permissive only in the beginning, to purchase land for the use of the railway it then became obligatory upon the company to use the land for the purpose for which it had been acquired.

By parallel reasoning, and in answer to the question whether the authority is imperative or merely permissive, perhaps it may successfully be argued that when a plant operator has submitted the plant construction and design plans and operating procedures to the Provincial Board of Health, and has obtained approval to proceed with them, the authority is permissive only; but, if the plant operator chooses to proceed, the authority is imperative that the plant operator proceed in strict accordance with the requirements contained in the Provincial Board of

$65[1899]$ A.C. 535.

S6 Id., at 544 .

67 Id., at 544-5.

68 Id., at 547 .

so [1925] 3 W.W.R. 202, aff'd. in [1926] S.C.R. 603.

60 Id., at $208-9$. 
Health's regulations and approval, and failure to do so at any time may result in punitive action. ${ }^{61}$

An important case in Alberta which dealt with the matter of statutory authority in circumstances like those that might obtain in the case of natural gas processing and sulphur recovery plants is Topham v. City of Edmonton. ${ }^{62}$ The plaintiff alleged that the smell from a sewage disposal plant had damaged the value of his property and had caused annoyance, discomfort and damage to health and that it was impossible for the plaintiff to continue to reside on his property. The plaintiff claimed damages and an injunction restraining the City of Edmonton from maintaing its sewage disposal plant at the place where it was located. The issue was whether the Edmonton City Charter and the Public Health Act ${ }^{63}$ were merely permissive and of such a character as not to authorize the construction of any works which might injuriously affect adjoining property owners, or whether in the alternative these legislative Acts came within the class of cases in which it is assumed the corporation might construct and maintain a sewage system whether or not a nuisance was created. There was no negligence in the construction, operation or maintenance of the sewage system and the plaintiff sued only in nuisance. In holding for the City of Edmonton, Chief Justice Simmons stated: ${ }^{84}$

I have no difficulty in arriving at the conclusion that the Acts, namely, The Public

Health Act and The Edmonton Charter, both creations of the provincial Legis-

lature, contemplated something more than mere permissive use of the said lands and that the case comes clearly within the principles set out in L.B. \& S.C. Ry. Co. v. Truman, supra, because The Public Health Act clearly requires the city to construct such plant in strict conformity with the requirements of the Provincial Board; and furthermore it gives the Provincial Board of Health very extensive powers in regard to supervision, construction, operation, maintenance, etc., of said works . ... and specifically provides for the construction, maintenance and operation of the same to be carried on without danger to public health and in that sense the legislation is not merely permissive but it is a necessary work contemplated under the said statutes and the powers that were intended to be incidental to the construction and operation of the same carried with them the right to maintenance irrespective of whether a common nuisance might arise or not; provided always that the said works were constructed and maintained without negligence. (Italics for emphasis)

The nuisance in the Topham case was odorous sewage which, although different in substance, is similar in effect to odorous waste gases from natural gas processing and sulphur recovery plants. It appears that there was great similarity in the powers exercised by the Provincial Board of Health in the Topham case over construction, maintenance and operation of the sewage disposal plant to those now exercised by the Provincial Board of Health over natural gas processing and sulphur recovery plants. In both cases the aim of the legislation was and is to protect the public health and in both there was and is the requirement that construction, maintenance and operation of plants be carried on without danger to public health. Thus, can it be said that, so long as the public health is not endangered, the plant operator may create a nuisance? The Topham case certainly can be taken to mean this. However, it is doubtful how much reliance may be placed on the Topham case. The Provincial Board of Health's air pollution re-

61 Ante, n. 45, s. 24 (4), (5) and (6).

G2 [1932] 1 W.W.R. 636 (S.C. Alta). See Clarke v. City of Edmonton, [1933] 1 W.W.R. 113

(S.C. Alta.) where, on facts similar to those in the Topham case, there was liability because the sewage disposal plant was belng operated negligently and such negligence caused a nuisance.

63 R.S.A. 1922, c. 58 .

64 Ante, n. 62, at 689-40. 
gulations came into effect after the Topham case. The regulations, rather than increasing, limit a plant operator's powers and make their exercise conditional upon required procedures being followed..$^{05}$ Nuisance is not expressly authorized by the Provincial Board of Health's plant approvals or regulations, ${ }^{, 6}$ and it is doubtful that nuisance is the inevitable consequence of that which the approvals and regulations authorize and contemplate. ${ }^{87}$ In this regard, consideration should be given to section 24 of The Public Health Act. Under section 24 aggrieved persons may complain to the Provincial Board of Health that dust, vapour, fumes or smoke are being discharged into the atmosphere and the quality of the air is being impaired or corrupted and the comfort or health of the public or a portion of the public is being injuriously affected. The Provincial Board of Health may investigate the complaint and recommend treatment by the person who it determines is responsible for the condition complained of, or the Minister may obtain an order from a court against the person responsible for the condition. It may be that section 24 is intended to provide a remedy to persons who would otherwise have no right to sue in nuisance; but the better view seems to be that section 24 merely arms the Provincial Board of Health and the Minister of Health with an effective and speedy means of providing relief as an additional remedy to aggrieved members of the public.

\section{Remedies for Injury from Waste Gases}

Injury to persons and property caused by the emission of odorous, noxious or toxic waste gases from natural gas processing and sulphur recovery plants is actionable. The basis of liability must be found in trespass, negligence, strict liability under the rule in Rylands v. Fletcher ${ }^{\circ 8}$ or, unless authorized, nuisance.

\section{Trespass}

Trespass is the proper form of action if the plaintiff's loss is the direct and not the consequential result of the defendant's act. ${ }^{.9}$ The difficulty of distinguishing between direct and consequential acts is pointed out by Street: ${ }^{0}$

How difficult it is to draw the line between "direct" and "consequential" acts is shown by Gregory v. Piper, which held that it was trespass where rubbish, which was placed near the plaintiff's land, on drying, rolled on to it, because this was the result of natural forces.

In contrast it was held in Southport Corporation v. Esso Petroleum Company Limitedi1 that where oil was discharged from a ship and carried on the tide to the plaintiff's foreshore the damage was consequential and not direct. Similarly, in Mann v. Saulnier ${ }^{72}$ it was held

os Raffan v. Canadian Western Natural Gas Company (1914), 6 W.W.R. 1295, 1297 (Alta. C.A.) ". . statutory provisions Imposing a restriction for the benefit of the public upon a company belng granted unusual powers should be liberally construed in the upon a company being granted unusual powers should
public interest ... Aff'd in (1915), 8 W.W.R. 676 (S.C.C.)

60 Groat v. City of Edmonton, [1928] S.C.R. 522, 533, rev'd. 22 Alta. L.R. 457 (Alta. C.A.) per Rinfret, J.: ". . statutory powers..." should not be understood as authorizing the creation of a private nuisance-unless indeed the statute expressly so states".

07 See Portage la Prairie (City) v. B.C. Pea Growers Limited (1966), 54 W.W.R. 477 (S.C.C.) and Lawrysyn v. Town of Kipling (1966), 55 W.W.R. 108 (Sask. C.A.) for recent pronouncements of these principles.

68 [1886] L.R. 3 H.L. 330 (H.L.).

69 The Laws of Torts (Street) 3d ed. (1963), at 62: "As with all forms of trespass, the immedlate act must constitute the trespass complained of; it is not trespass if the invasion of the plaintiff's land is merely consequential upon the act of the defendant."

70 Id., at 62 .

71 [1954] 2 All E.R. 561 (C.A. per Denning, L. J. at 570), and [1955] 3 All E.R. 864 (H. of L. per Lords Radcliffe at 872 and Tucker at 873 ).

72 (1959), 19 D.L.R. (2d) 130 (N.B.C.A.). 
that where the top of a fence, erect when originally placed on the boundary line, encroached a few inches over the adjoining land as a result of natural forces, the injury was consequential and not direct. ${ }^{7 s}$

On the basis of the foregoing authorities it is doubtful that a trespass has been committed where odorous, noxious or toxic gases have been emitted into the atmosphere from a plant and are thereafter carried by air currents to neighbouring land. It is submitted that neither the plant operator nor the plant owners and persons who supply natural gas to plants for processing are liable in trespass for injury to life and property caused by the emission of such gases into the atmosphere. ${ }^{i 4}$

\section{Negligence}

Liability of Plant Operator-The disadvantage in suing in negligence is that the plaintiff may have a difficult time in proving that the plant operator was negligent in operating the plant or that his negligence is the cause of the loss or injury suffered by the plaintiff. Commonly, there are other possible causes, such as sour gas wells in the vicinity of the plant, that may have contributed partially or totally to the plaintiff's loss or injury.

Liability of Plant Owners-If the plant operator is held to be negligent, the plant owners may be vicariously liable for the tortious acts of the plant operator. The liability of the plant owners will be determined by their legal relationship with the plant operator. ${ }^{73}$ In each case it will be necessary to characterize this relationship which is complicated by the fact that the plant operator is one of the plant owners, usually owns the largest interest in the plant and has an important voice in matters relating to plant operations. Because of the vast complexity of operations of natural gas processing and sulphur recovery plants and of the interplay between legal relationships and the dual capacity of the party operating the plant, it may be difficult in any given case to determine whether the plant operator, in committing negligence, acted in the capacity of a plant owner or as an independent contractor, partner, servant or agent of the plant owners. It is settled lawio that the plant owners will be responsible for the negligence of the plant operator while the latter acts in the capacity of a servant or agent, or, in some circumstances, independent contractor of the plant owners, or as a partner if the acts of the plant operator which give rise to the negligence occur in the ordinary course of the plant's operations or with authority of the plant owners.

Liability of Working Interest Owners-There are at least two circumstances in which the working interest owners who do not own the

i3 See Allen Phillips v. California Standard Company, Seismotech Ltd. and Sohio Petroleum Company (1960). 31 W.W.R. 331 (S.C. Alta.) which dealt with the problem of distinguishing between direct and consequential damage.

it Contra. The Law of Torts (Street) 3d ed. (1963), f.n. 2 at 63 where the author states: "Perhaps anything having size or mass, including gases, flame, beams from search llghts and mirrors, but not vibrations". entering upon or coming into physical search lights and mirrors, but not vibrations "entering upon or coming into physical contact with the land of the plaintiff is a trespass; but no cases in support of this
suggestion are cited. In Winfield on Tort 7 th ed (1963). at 434 it is stated cTrespass applies only to physlcal intrusions by tangible objects, be they persons or things, whereas nuisance extends also to invasion by noises. smells and vibrations."

is Plant Operating Agreements usually contain clauses which attempt to negate aniy interpretation that the relationship of the plant owners is that of a partnership, joint venture, association or trust, or that the plant owners have any partnership duty, venture, association or trust, or that the plant owners have any partnership duty, claim results from gross negligence or wilful misconduct of the operator or its emclaim results from gross negligence or wilful misconduct of the operator or its em-
ployees, agents or servants, the plant owners will indemnify and hold harmless the plant operator from third party claims or liability.

jo 28 Halsbury's Laws 22, s. 20; 513, s. 993 (3d ed. Simonds 1955). 
plant and have no control over its operations may be liable in negligence. If the working interest owners negligently deliver to the plant natural gas which contains deleterious substances and the plant is not designed to dispose of them properly and they are emitted into the atmosphere causing injury to persons or property, the working interest owners may be liable. ${ }^{77}$ The other circumstance, similar to that in Northwestern Utilities Limited v. London Guarantee and Accident Company, Limited, ${ }^{78}$ is where the emissions of deleterious substances which originated in the reservoir serving the plant are so conspicuous and long continuing that there is lack of due care on the part of the working interest owners if they do not know of them. In this case, although they would not be liable for injury caused, without their default, by the independent conscious act of the plant operator, they may be held to be negligent in failing to foresee and guard against the consequences of the emissions of the deleterious substances.

\section{The Rule in Rylands v. Fletcher-Strict Liability}

The classic statement of the rule in Rylands v. Fletcher is succinctly stated in the judgment of $\mathrm{Mr}$. Justice Blackburn in the Court of Exchequer Chamber in Fletcher v. Rylands. ${ }^{79}$

We think that the true rule of law is, that the person who for his own purposes brings on his land and collects and keeps there anything likely to do mischief if it escapes, must keep it in at his peril and, if he does not do so, is prima facie answerable for all the damage which is the natural consequence of its escape.

This statement was adopted by the British Columbia Supreme Court in Heard and Heard v. Woodward ${ }^{80}$ where it was decided that Rylands v. Fletcher goes "so far as to make absolute the duty of the generator of noxious fumes to so contain them as to render it impossible for them to constitute a nuisance to the neighbours". The plaintiff was awarded nominal damages of $\$ 50.00$ and was entitled to an injunction to restrain the defendant from permitting noxious fumes to escape from his premises into those of the plaintiff. In Mortimer v. British American Oil Company Limited $^{81}$ the plaintiff alleged that noxious fumes or dangerous gases came from British American's petroleum refining plant which was located approximately twenty feet from the plaintiff's home. The trial judge found that no negligence had been proven against the defendant nor did res ispsa loquitur apply. The trial judge inferred from the evidence that the source of the gas or fumes was British American's plant and applied Rylands v. Fletcher to award the plaintiff the sum of $\$ 846.80$ for damages he had sustained. In dismissing British American's appeal to the Appellate Division of the Supreme Court of Alberta, Mr. Justice J. H. Macdonald stated that: ${ }^{82}$

In Read v. Lyons \& Co. Ltd., [1947] A.C. 156, [1947] LJR 39, [1946] 2 All ER 471, a decision of the House of Lords, their Lordships discussed the scope of the rule

7728 Halsbury's Lazos 32, s. 28 (3d ed. Slmonds 1955).

78 [1936] A.C. 108, aff'd. (1934), 3 W.W.R. 641 (Alta. C.A.). The facts were that a publlc utility company supplied the City of Edmonton with natural gas. The clty authority in constructing a storm sewer underground, fractured a joint in one of the main plpes of the public utility company through which gas was carried to consumers. The gas subsequently percolated through the soll, penetrated the basement of plaintiff's hotel, ignited there and destroyed the hotel. It was held that the public utility was liable even though the clty authority's negligence caused the escape of the gas.

79 1866 I.R. 1 Ex. 265, 279-80. This statement was approved in The House of Lords [1868] L.R. 3 H.L. 330 .

80 (1954) 12 W.W.R. 312 . The use of "absolute" may be a misnomer, as there are posstble defences to Rylands $v$. Fletcher. Correctly, the liability may be strict; but it is not absolute.

$81[1950] 1$ W.W.R. 49 (S.C. Alta.). See also Lohndorf and Alberta General Insurance Company v. British American Oil Company Limited (1958), 24 W.W.R. 193.

82 Id., at 54. 
in Rylands v. Fletcher, supra, and the general principle on which it is founded. Viscount Simonds at p. 166 of the Law Reports quotes the proposition laid down in Rylands v. Fletcher by Blackburn, J.:

"The person who for his own purposes brings on his lands, and collects and keeps there, anything likely to do mischief if it escapes, must keep it in at his peril, and if he does not do so, is prima facie answerable for all the damage which is the natural consequence of its escape."

(The italics are, of course, mine.)

He then continues at p. 168:

"Escape" for the purpose of applying the proposition in Rylands v. Fletcher means escape from a place where the defendant has occupation of, or control over, land to a place which is outside his occupation or control."

The source of the gas being the defendant's refining plant, there is no doubt that the defendant is liable for the damages found by the trial judge.

The appeal should be dismissed with costs.

These cases indicate the ease with which courts have applied Rylands v: Fletcher to find liability for escape of noxious gases. It is doubtful that the Alberta courts can, in the light of the Mortimer case, be persuaded that a natural gas processing or sulphur recovery plant is not a "non-natural user" of land; but it should not be over-looked that the strict liability recognized by the House of Lords to exist in Rylands v. Fletcher is conditioned by two elements which must exist before strict liability can be found. One is the condition of "escape" from the land of something likely to do mischief if its escapes, and the other is the condition of "non-natural use" of the land. ${ }^{33}$ In both the Woodward and the Mortimer cases there was an "escape"; however, it appears that no consideration was given to whether the source of the nuisance was a "non-natural user" of the defendant's land. Thus, there may be yet an opportunity to argue that a natural gas processing or sulphur recovery plant in a particular place, such as a sour gas producing region, is a natural user of the land and that no liability obtains under the rule in Rylands v. Fletcher.

Applicability to Personal Injuries-Although Rylands v. Fletcher may be applicable in an action by the plaintiff for injury to property caused by escaping waste gases there is doubt whether the rule also applies to a claim for injuries to the person. ${ }^{84}$ In the leading case of Read v. J. Lyons \& $\mathrm{Co}^{85}$ this question was considered by all of the Lord Justices but not decided. In that case a female inspector under the National Service Act of England was carrying out her duties in a shell-filling factory when one of the shells exploded killing a workman and injuring her. The House of Lords was unanimously of the opinion that the rule in Rylands v. Fletcher did not apply unless the dangerous thing escaped from the lands upon which it was brought and that since the explosion and injury occurred in the shell-filling factory the rule could not apply to that case. In answer to the claim for personal injuries, the majority of their Lordships expressly refrained from deciding whether the claim by virtue of the principle in Rylands v. Fletcher lay for personal injuries. Lord Uthwatt stated:

I do not regard Rylands v. Fletcher as laying down any principle other than a principle applicable between occupiers in respect of their land or as reflecting

8s Read v. Lyons \& Co., [1947] A.C. 156, 167.

84 But see 28 Halsbury's Laws s. 192, f.n. “(k)" (3d ed. Simonds 1955) and Winfield on Tort, 7 th ed. (1963) at 446, f.n. 39, where occupiers and non-occupiers have recovered damages for personal injuries under the rule in Rylands $v$. Fletcher. In The Law of Torts (Street) $2 d$ ed. (1959), at $251-2$, it is suggested that the rule in Rylands $v$. Fletcher applies to actions for personal injuries by owners, occupiers and persons with no interest in the land affected.

85 Ante, n. 83. 
an aspect of some wider principle applicable to dangerous businesses or dangerous things. 86

Lord MacMillan based his opinion squarely on the proposition that the rule in Rylands v. Fletcher

derives from a conception of mutual duties of adjoining or neighbouring landowners and its congeners are trespass and nuisance. ${ }^{87}$

He further stated that if

its foundation is to be found in the injunction sic utere tuo ut alienum non laedas, ${ }^{88}$ then it is manifest that it has nothing to do with personal injuries. . . . The two pre-requisites of the doctrine are that there must be the escape of something from one man's close to another man's close and that which escapes must have been brought upon the land from which it escapes in consequence of some non-natural use of the land, whatever precisely that may mean. ${ }^{80}$

This statement of Lord MacMillan was merely obiter dictum and one which the other members of the House of Lords expressly refrained from assenting to, but the general view of the Lord Justices in Read v. $J$. Lyons \& Co. was that damages for personal injuries cannot be recovered by a plaintiff suing under the rule in Rylands v. Fletcher, and if the question had then been necessary to decide, the House of Lords would have so held. However, subsequent cases $^{90}$ have held to the contrary and the plaintiff has recovered damages for personal injuries under the rule in Rylands v. Fletcher. In the Canadian case of Aldridge and O'Brien v. Van Patter et al, ${ }^{91} \mathrm{Mr}$. Justice Spence held that: ${ }^{92}$

I am of the opinion, therefore, in view of the cases in the English Court of Appeal which I have cited, that a Court is justified in finding a liability under the principle of Rylands v. Fletcher for personal damages, and for personal damages sustained not by the owner or occupant of adjoining lands but by anyone to whom the probability of such damage would naturally be foreseen.

Whether the Aldridge case will be the basis of the law in Canada is uncertain. The comments of the Lord Justices, especially of .Lord MacMillan, in Read v. J. Lyons \& Co., are still of very persuasive value and the Aldridge case may be anomalous and restricted to cases involving negligence. In view of the uncertainty in the law and of the existence of authority for and against recovery of damages for injuries to the person, the question of whether a plaintiff can recover damages for injury to his person is open.

Liability of Plant Operator-The person liable under the rule in Rylands v. Fletcher is the person who exercises control over the thing that escapes, i.e., the plant operator, and an owner out of possession of the land at the time injury takes place is not liable under the rule. ${ }^{93}$ This proposition was espoused in St. Anne's Well Brewery Co. v. Roberts ${ }^{94}$ by Lord Justice Scrutton who stated: ${ }^{95}$

. . as I understand the doctrine of Rylands v. Fletcher it relates to occupiers. I do not know ... any case where the doctrine ... has been applied to an owner not in occupation.

88 Ante, n. 83, at 186.

87 Ante, n. 83, at 170-3.

88 "Use your own property in such a manner as not to injure that of another". The expression has been criticized as mere verbiage and of no help to a decision because it begs the question and assumes the very point in controversy.

89 Ante, n. 83, at 173.

90 Ante, n. 84.

91 [1952] 4 D.L.R. 93 (Ont. H. Cft.).

92 Id., at 105.

9328 Halsbury's Laws 158, 222 (3d ed. Simonds).

94 [1928] All E.R. 28 (C.A.). This statement should be contrasted with the position in nulsance of the non-occupler of the land on which the nuisance originates who in certain instances is liable, e.g. landlords.

95 Id., at 30 . 
In the same case Lord Justice Greer stated: ${ }^{98}$

Rylands v. Fletcher has never been applied to effect the liability of an owner who is out of possession at the time that the injury takes place.

Liability of Plant Owners-There are obiter dicta in cases ${ }^{97}$ that throw doubt on the accuracy of these statements in the St. Anne's case so that it appears that the plant owners, who are not in occupation of the land when the waste gases escape, may be liable if they have authorized the accumulation of the deleterious substances on the plant premises.

Liability of Working Interest Owners-It is unlikely that the working interest owners of the reservoir who deliver the deleterious substances to the plant and who neither own any part of the plant nor control its operations could be liable under the rule in Rylands v. Fletcher, and if the plant operator had no knowledge of the existence of the deleterious substances on the plant premises or could not have controlled their escape, it is unlikely that it would be liable under the rule in Rylands v. Fletcher.

Geographical Extent of the Rule-There seems to be no authority that clearly limits the farthest point at which the thing that escapes will cease to create liability under the rule in Rylands v. Fletcher, but it is clear that the occupier's liability is not limited to injuries to adjacent premises. In Charing Cross Electricity Supply Company v. Hydraulic Power Company ${ }^{98}$ Lord Sumner stated: ${ }^{90}$

$\therefore$. I am satisfied that Rylands v. Fletcher is not limited to the case of adjacent

freeholders. I shall not attempt to shew how far it extends.

In the Charing Cross case, Mr. Justice Bray suggested that liability will lie for any mischief occasioned, irrespective of the distance from the occupier's premises: ${ }^{100}$

$\ldots$ if he brings upon his land anything which would not naturally come upon it, and which is in itself dangerous, and may become mischievous if not kept under control, ... he will be liable in damages for any mischief thereby occasioned ... that is to say, not mischief necessarily occasioned to the owner of the adjoining land, but any mischief thereby occasioned. (Italics for emphasis)

Thus, no matter how far from the plant the waste gases travel and cause injury, liability may be with those responsible for their emission from the plant.

\section{Nuisance}

At first blush it appears there is no importance in whether a plaintiff seeks relief in nuisance or under the rule in Rylands v. Fletcher. The decided cases have repeatedly treated Rylands v. Fletcher as if it were a mere species of the wrong comprised in nuisance. Thus, it would seem pointless to consider nuisance under a separate head. However, Winfield on Tort $^{101}$ points out a number of differences between the two torts.

The principles which have been applied to determine whether an action in nuisance ought to succeed are contained in numerous decided cases and in text books which deal with the subject of nuisance. ${ }^{102}$ The

96 Id., at 35 .

97 Winfield on Tort, 7 th ed. (1963), at 448 and cases in $f . n$. 50 thereof.

08 [1914] 3 K.B. 772 .

99 Id., at 779 .

100 Id., at 785 .

101 7th ed. (1963), at 465-7. See criticism of Winfield on Tort in The Law of Torts (Street), 2d ed. (1959), at 257-8, but which has been deleted without comment from the 3d. ed. (1963), at 255-77.

102 Winfield on Tort, fth ed. (1963): General Principles of the Law of Torts, 2d ed. (1964)

The Law of Torts (John G. Meming) 3d ed. (1965); Clerk \& Lindsell on Torts, 12th ed

(1961); The Law of Torts (Street), 3d ed. (1963). 
plaintiff in order to commence an action in nuisance must have some title to the land which is subject to the nuisance. Generally, the plaintiff is the person in actual possession of the land, but it must be someone who has a proprietary or possessory interest in the land. ${ }^{103}$ Mere users of the land, without either the possession of it or any proprietary interest in it, may not sue in nuisance even though they have suffered direct personal or pecuniary damage. ${ }^{104}$ Thus, the occupier's spouse, family, servants or guests cannot sue; although, in Alberta, it may be that the spouse of the occupier of the land which is the homestead may have a sufficient proprietary interest by virtue of The Dower Act. ${ }^{105}$ Nuisance may consist of some interference with the beneficial use of, or physical injury to, the premises. When an action in nuisance is based on mere discomfort or inconvenience, the discomfort or inconvenience must be substantial-that is to say, it must not be merely trifling or fanciful or such as an average or reasonable man is content to submit to. The standard is variable depending on the locality and whether the average man who resides in the locality would suffer the substantial discomfort or inconvenience of which the plaintiff complains. ${ }^{100}$ However, the doctrine of the local standard of comfort does not apply where the nuisance causes a physical injury to property, or sensibly reduces its value. ${ }^{107}$ Though the courts have protected delicate or sensitive trades such as mink farms and fruit orchards, no action will lie in respect of damage which, even though substantial, is due solely to the fact that the plaintiff is abnormally sensitive to deleterious influences. ${ }^{108}$

Applicability to Personal Injuries-Salmond on the Law of Torts ${ }^{100}$ states that the emphasis on the proprietary character of the action in nuisance raises doubts whether damages can be recovered for personal injuries and that there seems to be no case which definitely either affirms or denies the right, although there is obiter dictum in the Canadian case of Ingle v. Hanson" 11 that "(An) action for private nuisance is correctly confined to injuries to property: Cunard v. Antifyre . . a at 556-7." In Cunard v. Antifyre Ltd.111 the plaintiff sued, inter alia, in nuisance for damages arising from injuries caused to the plaintiff when a heavy piece of guttering fell from a roof of a building through the glass roof of plaintiff's kitchen causing broken glass to strike the plaintiff and injure her. Mr. Justice Talbot, speaking for the court, stated that: ${ }^{112}$

(We) think that some confusion has been caused by the use of plaintiffs both in their particulars of claim and in their notice of appeal of the word "nuisance". We think that nuisance (we are talking of private nuisance only) is correctly confined to injuries of property ... as by ... noxious vapours ... or the like. In all such cases the plaintiff to maintain an action must show some title to the thing to which the nuisance is alleged to be ... and this follows from the nature of such action.

It should not be supposed that the principle of the Cunard case deprives the plaintiff of any recovery for personal injury. Damages may be obtained for personal injury in nuisance where the injury results from interference with use or enjoyment of land which gives rise to such in-

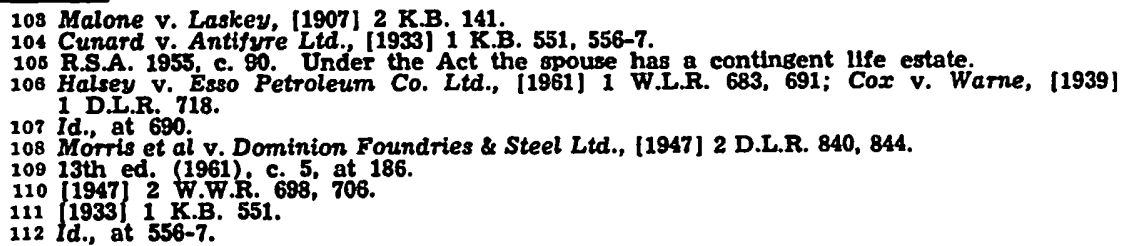


jury, as where plaintiff's health is impaired by a nuisance which renders his home an unhealthy place in which to live. If, however, on authority of the Cunard case, the claim is for personal injury only it must be founded in negligence and not in nuisance.

There are numerous cases in Canada which have held that a person who allows odorous or noxious substances to escape from his land to the land of his neighbours is, within the boundaries of the foregoing principles, liable to his neighbours for nuisance. In some of the more notable cases nuisance was found in emitting odorous and noxious gases from oil refineries, ${ }^{113}$ sulphurous smoke from a brick-making plant, ${ }^{114}$ noxious acid smuts and smells from an oil marketing depot, ${ }^{115}$ metal malodorus fumes from a machinery-manufacturing business ${ }^{116}$ and smoke and fumes from burned fuel oil."17

Liability of Plant Operator-Under the authority of these cases there is little doubt that the plant operator is liable in nuisance for the escape of odorous, noxious or toxic gases which cause substantial interference with the beneficial use or physical injury to lands, but there is some doubt whether it is liable for personal injuries suffered as a consequence of the nuisance.

It is settled law that the occupier of the premises where the nuisance exists is in general liable during the period of his occupancy.118 The plant operator is usually the only party in occupation of the plant premises and if the plant operator or its servants or agents caused the nuisance which resulted in personal injury to plaintiff, the plaintiff could, assuming he could maintain an action in nuisance, recover his loss against the plant operator. There is no doubt that the plaintiff with a proprietary or possessory interest in the land affected could succeed against the plant operator for substantial intereference with the use and enjoyment of his property or physical injury to it.

Liability of Plant Owners-Some doubt exists about the liability of the plant owners for nuisance. Usually they are not "occupiers" in the sense that they physically inhabit the plant premises. It is submitted, however, that it would be ludicrous if the law allowed recovery against the plant operator but not against the plant owners merely because the latter are not occupiers. Here again the significance of the legal relationship between the plant owners and the plant operator is manifest. The correct view is probably that the ordinary rules of vicarious liability in tort apply and the plant owners are, within the limits of these rules,

113 Huston et al v. Lloyd Refineries Ltd., [1937] 0.W.N. 53. Plaintiff was awarded an injunction preventing defendant's interference with plaintiff's beneficlal enjosment of property and damages for injury to property and health by odours from an of refinery that were "offensive, nauseating and causing irritation to the throat and refinery that were "offensive, nauseating and causing irritation to the throat and nasal passages", but not an absolute Injunction "Which would destroy an investment of half a million dollars where adequate relief might be granted by aparding damases".
Godfrey v. Goodrich Refining Co. Ltd., [1940] 2 D.L.R. 164, 167 aff'd. [1939] O.R. 106. Plaintiff complained of intermittent passages over her country estate of noxious 8ases produced from refining sour crude. In the absence of injury to property or health no damages were awarded but plaintiff was granted an injunction restraining operator from allowing the gases to interfere with plaintiff's enjoyment of her property.

114 McNiven et al v. Crawford, [1940] O.W.N. 323 (Ont. C.A.). Damages were awarded to plaintiff who suffered a loss from defollation of peach trees when smoke from a to plaintiff who suffered a loss from defoliation of peach trees when smoke from a brick-making plant containing noxious fumes and sulphur dioxide gas passed through
the trees. See also Smith v. Consolidated Mining and Smelting Co. of Canada (1909). 11 W.L.R. 488 for nuisance in operating a smelter.

11. Halsey v. Esso Petroleum Ltd., [1961] I W.I.R. 683. Plaintiff recovered damages and was awarded an injunction against the owners and occuplers of an oil storage and issulns depot for committing a nuisance by alr pollution by noxious acid smuts and smells. Rylands v. Fletcher was also applied.

116 Smith v. Coutts Machinery Company Limited, [1926] 3 W.W.R. 326 (S.C. Alta.).

117 Cubbon v. White, [1938] 2 W.W.R. 257.

118 Winfield on Tort, 7th ed. (1963), at 419. 
liable for the acts of the plant operator under their control. ${ }^{110}$ In Mantania v. Nat. Prov. Bank ${ }^{120}$ it was stated: ${ }^{121}$

$\ldots$ if the act done is one which in its very nature involves a special danger of nuisance being complained of ... the employer of the contractor will be responsible if there is a failure to take the necessary precautions that the nuisance shall not arise.

This statement may, however, have only limited significance in the case of modern natural gas processing and sulphur recovery plants. Plant owners expend thousands of dollars in devices to reduce air pollution and prevent injury and damage. The most common devices are specially designed waste gas disposal stacks which are constructed at great expense to emit the odorous, noxious or toxic gases into the atmosphere hundreds of feet above the ground.

It may be, too, that the legal obligations of plant owners, vis a vis the plant operator, are analogous to that of landlords, vis a vis their tenants. In general, the landlord is not liable for a nuisance on the premises because he is not in occupation; the proper person to sue is the tenant. ${ }^{122}$ But the landlord is liable if he has expressly or impliedly authorized his tenant to create a nuisance. In such a case the liability of the landlord is the same as any principal who authorizes his agent to commit a tort. The tenant, of course, is also liable. ${ }^{123}$

Liability of Working Interest Owners-It is unlikely that the working interest owners who own no part of the plant and have no control over its operations could be held liable for a nuisance created by emissions of waste gases from the plant even though the deleterious substances in the waste gas which caused the nuisance were delivered from their reservoir to the plant.

\section{Conclusions}

The following conclusions can be made:

(1) Without proper control of emissions of plant waste gases there is a danger of air pollution which could result in injury to life and property and interference with use and enjoyment of land. The principal pollutants are hydrogen sulphide, sulphur dioxide and mercaptans.

(2) Air pollution by plants is controlled in Alberta by the Provincial Board of Health under authority of The Public Health Act and Air Pollution Regulations.

(3) The Public Health Act and Air Pollution Regulations give the Provincial Board of Health very extensive powers in regard to supervision of construction and operation of plants. Where the construction and mode of operation of a plant have been authorized by the Provincial Board of Health and every reasonable precaution consistent with the exercise of the authority has been taken to prevent the occurrence of nuisance from air pollution, it may be that all remedies to prevent the nuisance or to recover damages are gone.

110 Id., at 419.

120 [1936] 2 All E.R. 633 (C.A.).

121 Id at 646 per Slesser, I.J.; and at 651 per Finlay, J.: “. . . this is not a case of mere ordinary building operation $(s) ;$ it is a case where unless precautions were taken there was a great and obvious danger that nuisance would be caused. . .."

122 Winfield on Tort, 7 th ed. (1963), at 423.

123 Ibid., eg. A let a field to B for working it as a lime quarry and B's acts in blasting the limestone and letting smoke escape from the kilns constituted a nuisance to $C$. $A$ was held liable, for B's method of working the quarry was the usual way of getting A was held liable, for B's method of working the quarry was the usual way of getting Tort, 7 th ed. (1963), at 423 . 
(4) Injury to persons and property caused by the emission of odorous, noxious or toxic gases from plants is actionable. The basis of liability must be found in trespass, negligence, strict liability under the rule in Rylands v. Fletcher or, unless authorized, nuisance:

Negligence-The plant operator is liable for injury to persons and to property caused by its negligence in emitting deleterious waste gases from the plant. Plant owners are vicariously liable for the negligence of the plant operator if, when the negligence occurred, the plant operator was the servant or agent, or, in some circumstances, independent contractor of the plant owners, or in partnership with them. The working interest owners of the reservoir are normally owners of the plant, and in that capacity, are liable, but where they merely deliver the deleterious substances to a plant which they neither own nor control, they are not liable, but they may be liable for injury to persons and property caused by their negligence in delivering to the plant natural gas which the plant is not designed to process or in permitting the conspicuous and long-continuing emission from the plant of deleterious waste gases which originated in their reservoir.

Rule in Rylands v. Fletcher-The question of whether a plant is a "non-natural" user of land in all circumstances is unanswered. Where it is a natural user the rule has no application; but where it is a nonnatural user of land and deleterious waste gases "escape" from the plant, the plant operator is liable under the rule because it is in occupation of the plant and has control of the deleterious waste gases that escape. Plant owners, even though they are not "occupiers" of the plant premises, probably are vicariously liable if they authorize the emission of deleterious waste gases into the atmosphere. The working interest owners of the reservoir are normally owners of the plant, and in that capacity, are liable, but where they merely deliver the deleterious substances to a plant which they neither own nor control, they are not liable. Uncertainty exists whether there is liability for personal injuries caused by the escape of deleterious waste gases from the plant.

No matter how far from the plant the waste gases travel and cause injury, liability may be with those responsible for their emission from the plant.

Nuisance-Nuisance caused by emission of deleterious waste gases may consist of some substantial interference with the beneficial use and enjoyment of, or physical injury to, land to which the plaintiff has "title". In either case, and except where there is statutory authority to commit a nuisance, the plant operator, as occupier of the plant premises, is liable to the plaintiff and probably the plant owners are vicariously liable to the plaintiff. For the reasons expressed above under the rule in Rylands v. Fletcher the working interest owners are not liable for the nuisance caused to the plaintiff.

It is doubtful that an action in nuisance extends to a plaintiff whose claim is founded on personal injury unaccompanied by some substantial interference with the beneficial use and enjoyment of, or physical injury to, his land. 